\title{
THE EFFECTIVENESS OF STIMULATION TO THE TOILET LEARNING ABILITIES OF TODDLER
}

\author{
Maria Ulfa \\ Midwifery Department, Patria Husada Blitar School of Health Science \\ email: ulfamaria845@gmail.com
}

\begin{abstract}
Toilet learning in children is an attempt to train children to be able to control in defecating and urinating. The aim of this research was to determine the effectiveness of stimulation to the toilet learning ability of toddler. The research usedPre-Experimental One-Group Pre-test-post test design. The sampling technique used purposive sampling. The statistical test used wilcoxon signed rank test. The population was 14 toddler of PosyanduBendowulungKabupatenBlitar. The result showed that there was an effect of stimulation to the ability of toilet learning of 1 to 3 years old toddler. The Statistical test result using Wilcoxon sign rank test obtained p value $=0,000(<0,05)$. It is expected to increase knowledge about the implementation of toilet learning stimulation, especially for parents to make their children more independent.
\end{abstract}

Keywords: Stimulation, Toilet learning.

\section{INTRODUCTION}

Children go through growth and development stage since birth until adult. In infant stage the growth and development of children occurs very quickly. The attention given to under five years children will greatly determine the quality of human life in the future. Children under the age of five are in their golden period since the growth and development is very fast, so when the toddler experiencing disturbance in growth and development this stage it will have a major impact on the lives of children itself. (Nursalam, et al, 2008).

Toilet learning in children is an attempt to train children to be able to control the urination or defecation. Toilet learning in general can be implemented on every child who begin to enter the independence stage. This stage usually occurs in children aged 18-21 months. In doing the toilet learning, children need physical, psychological and intellectual preparation. By having those preparations, children can control the defecation and urinate independently (Nursalam, et al, 2008).

In addition to prevent the occurrence of bedwetting and starting a clean and healthy life behavior of children from an early age, toilet learning can also establish self-reliance and confidence in controlling urination and defecation, practicinggross motoric skills by walking, sitting, squatting, standing and also the ability of fine motoric skill by removing and wearing their own pants after urinating and defecating. It can also train the intellectual ability of the children by imitating the proper behavior such as urinate and defecate in the right place (Cahyaningsih, 2011).

Parents used toddler (1-3 years old) to start toilet learning since at that age almost all of the body functions is mature and stable, have great curiosity, interested in what is done by people around, and the child has entered the anal phase of pleasure center children on the behavior of withholding and also the excretion of impurities (Cahyaningsih, 2011).

Generally the instruction of toilet learning done by parents is $31 \%$ start to teach at the age of $18-22$ month, 27\% start at the age of 23-27 months, and $16 \%$ at the age of $28-32$ months and $22 \%$ at the age of more than 32 months. Parents wait for children to be ready to be taught toilet learning so that it does not take a long time (Warner, 2007). 
In preliminary study conducted on 22 February 2016 in Bendowulung village researchers found that from 10 mothers as the sample, showed that $70 \%$ of parents did not know how to stimulate toilet learning, $20 \%$ people fairly understood how to stimulate toilet learning, $10 \%$ parents understood about how give toilet learning stimulation.

Based on the problem of stimulation of toilet learning and the high percentage of children who still experience failure in toilet learning, it is necessary to give special attention to both parents and health workers, so the researchers interested in conducting study with the title The Effectiveness of Stimulation to the Toilet Learning Abilities of Toddler

The general objective of the study was to find out the effectiveness of stimulation to the ability of toilet learning in toddler. The specific objective was (1) Identifying the ability of toilet learning before being given stimulation (2) Identifying the ability of toilet learning after being given stimulation (3) Analyze the effectiveness of stimulation to the ability of toilet learning in toddler. The benefits for respondents is it can increase parents' knowledge about parenting in the implementation of toilet learning and parents are able to apply toilet learning to their children well. The researcher hopes that this study will improve the ability of children in doing toilet learning in accordance with parenting patterns applied by parents.

\section{METHOD}

This study used pre experimental design with One-Group Pre-test-post test. The subject of this study was 15 children in Posyandu Bendowulung kabupaten Blitar by purposive sampling in 10-15 July 2016. The instrument used an observation sheet prepared by researchers about toilet learning in toddler. The independent variable was stimulation about toilet learning in toddler. The dependent variable was the ability of toilet learning of toddler, while the data analysis used Wilcoxon statistic test.

\section{RESULT}

The result of the study included toddler characteristics and specific data of the study
Table 1 The Distribution of respondents' characteristics (toddler)

\begin{tabular}{llcc}
\hline No & Characteristics & f & \% \\
\hline 1 & Age & & \\
& $1-2$ year old & 7 & 46,7 \\
& $2-3$ year old & 8 & 53,3 \\
\hline 2 & Mothers' educational background & & \\
& Elementary & 1 & 6,7 \\
& Junior High & 7 & 46,6 \\
& Senior High & 6 & 40 \\
& College & 1 & 6,7 \\
\hline 3 & Mothers'occupation & & \\
& Housewife & 7 & 46,6 \\
& Entrepreneur & 7 & 46,6 \\
& State employee & 1 & 6,7 \\
\hline 4 & Siblings & & \\
& 1 - 2 & 10 & 66,7 \\
& $3-4$ & 4 & 26,6 \\
& $>4$ & 1 & 6,7 \\
\hline 5 & Environment & & \\
& Support & 13 & 86,7 \\
& Not support & 2 & 13,3 \\
\hline
\end{tabular}

Table 2 The Identification of Toddler Toilet Learning Before Stimulation

\begin{tabular}{llcc}
\hline No. & Ability & $\mathbf{f}$ & $\mathbf{\%}$ \\
\hline 1. & Good & 0 & 0 \\
2. & Fair & 2 & 13,3 \\
3. & Less & 13 & 86,7 \\
\hline & Total & $\mathbf{1 5}$ & $\mathbf{1 0 0}$ \\
\hline
\end{tabular}

Table 3 The Identification of Toddler Toilet Learning After Stimulation

\begin{tabular}{llcc}
\hline No. & Ability & $\mathbf{f}$ & $\mathbf{\%}$ \\
\hline 1. & Good & 12 & 86,7 \\
2. & Fair & 3 & 13,3 \\
3. & Less & 0 & 0 \\
\hline & Total & $\mathbf{1 5}$ & $\mathbf{1 0 0}$ \\
\hline
\end{tabular}

Table 4 The Analysis of the Effectiveness of Stimulation to the Toilet Learning of Toddler

\begin{tabular}{llcc}
\hline No & Ability & $\begin{array}{c}\text { \% before } \\
\text { stimulation }\end{array}$ & $\begin{array}{c}\text { \% after } \\
\text { stimulation }\end{array}$ \\
\hline 1. & Good & 0 & 86,7 \\
2. & Fair & 13,3 & 13,3 \\
3. & Less & 86,7 & 0 \\
\hline \multicolumn{2}{l}{ Wilcoxon signed rank test: $\mathrm{p}$ value $=0,000$} \\
\hline
\end{tabular}




\section{DISCUSSION}

\section{Toilet Learning Ability of Toddler before Stimulation}

Based on the results conducted at Posyandu Desa Bendowulung Blitar, showed that almost all $(86,7 \%)$ children $1-3$ years old had less ability in doing toilet learning before given the stimulation. Toilet learning was a learning effort for the child to be able to control defecation and urination so that children did not pee and poop on their pants by emphasing on the physical and mental readiness of the children. The age of toddler is age 1 to 3 years. The task of toddler age development is to establish self-reliance. The task of parents at this age is to support the growth of children's independence with patience and sensitivity. The less ability of toilet learning in toddler-age children in this study indicated the child did not have independence to urinate and defecate. It was caused by the children age, mother's educational background, and the number of siblings.

The presentation of toilet learning ability was not very high due to the lack of knowledge of the mothers who only introduced the importance of toilet learning and prepared it gradually. Uncontrolled condition could be done since in the age of $9-18$ months (Nursalam, 2013). It was not well known to the mother to teach and controlled their children to be able to perform their own toilet learning although it's the right time to teach. Children should have physical and mental readiness to perform toilet learning at this age.

The result of the study indicated almost half of the mother $46,7 \%$ were junior high school graduates. The ability to practice was a part of the behavior. According to the theory of Skinner (1938) in Notoatmodjo (2005) suggested that behavior was the result of the correlation between stimulus and response. The ability to practice could also be influenced by several things: knowledge as stimulus (stimulus) and family response to do it (response). Knowledge was a very important domain for the formation of one's actions (overt behavior). The higher the level of education was expected to increase the knowledge level of a person making it easier in receiving / adopting good behavior. A person with a very high degree of knowledge would be different from a low educated person. Mothers with junior high school educational background did not have the ability to adopt information well or even got nothing about toilet learning in toddler. Mother as the closest person to the child must have good knowledge to promote the ability and development of a good child as well.

Based on the results of the study showed most children $66.7 \%$ had1-2 siblings. Knowledge was also influenced by the number of children and experience in teaching toilet learning in toddler. Mother who had the first child time taught were inexperienced in giving toilet learning to her child. Mother inexperience in doing toilet learning in children since they did not know, understand, and analyze about toilet learning in toodler.

\section{Toilet Learning Ability of Toddler before Stimulation}

Based on the results of the study, almost all $(80 \%)$ of the children had good ability in doing toilet learning after being given stimulation. According to MOH RI (2006) stimulation was an activity to stimulate the basic ability of children for children to grow and develop optimally. Every child needed to get regular stimulation as early as possible and continuously at every opportunity. Lack of stimulation could lead to development and even sedentary disorders. Children development stimulation could be done by mothers and fathers who are the closest relatives to children, substitutes or caregivers, other family members and community groups in daily life. The ability of good toilet learning after being given stimulation affected by the age of the child, the mother's work and the child's environment.

Toddler age was the golden periodsince they experienced growth and development very quickly, so when the toddler experiencing disturbance in growth and development at this stage it will have a major impact on the lives of children itself. (Nursalam, et al, 2008). In this golden period children began to be sensitive to various stimuli, every children individually would have different levels of sensitivity of development (Nursalam, 2013). At that age almost all of the body functions were mature and stable, had great curiosity, interested in what the surrounding people do, and the child entered the anal phase of the child's pleasure center on the stifling behavior as well as the defecation.

Result of the study showed almost half the mother of the child was a housewife. Stimulation of child growth was done by parents who are the closest relative to children, substitute mother or 
nanny, members of other groups and community groups in the household and in daily life (Depkes RI, 2006). Stimulation was crucial to optimize the growth and development of children with the participation of parents and home environment in order to facilitate the necessary stimulation. Housewives had more time and concentration in teaching things to improve the growth and development of children, especially in teaching toilet learning.

The results showed almost all of the children's environment supported the stimulation of toilet learning. According to Notoatmodjo (2006), the environment was one of the factors that affect one's ability. The environment provided the first social influence for a person, where one could learn good things, also bad things depending on the nature of the group. Supportive environment was very good to stimulate children until they were able to do toilet learning independently. Toilet learning that was taught continuously was to hold urinating and defecating, to wash hands with soap and running water before come out of the bathroom.

\section{The effectiveness of stimulation to the toilet learning ability of toddler}

Based on the result of the study showed that there was an increase of percentage of toilet learning ability in toddler before and after being given stimulation that was less ability become good ability as $66,7 \%$ and from fair ability become good ability as $13,3 \%$. Based on statistical test of Wilcoxon Signed Rank Test obtained $\mathrm{p}$ value $=0.000$, so $\mathrm{p}$ value $=0,000<a ́=0,05$ indicated an effect of stimulation to ability of toilet learning at child age toddler at Posyandu Desa Bendowulung Blitar. The effect of stimulation on the ability of toilet learning in children toddler indicated that stimulation could help the children to the optimal development, especially the independence of children to do toilet learning.

Stimulation was a part of children basic needs, namely "asah". By polishing the ability of children continuously, the ability of children would increase. The stimulation could be done by exercise and play. Children who received targeted stimuli would develop faster than children who were less stimulated (Nursalam, et al, 2008). Stimulation did not always require special time, so it could be linked together with other activities and done every day for example associated with the mother's activities when doing homework and given when traveling with children, bathing the children, feeding the children, putting the children to sleep, and so on. However, the stimulation should be done according to the basic principles that were needed to be considered, the stimulation was done with the basis of love and affection and always shows good attitude and behavior because the child would imitate the behavior of those closest to him. Stimulation in the form of teaching toilet learning, in addition to prevent the occurrence of bedwetting and creating a clean and healthy life behavior in children early, toilet learning would also establish independence and confidence in controlling urination and defecation.

\section{CONCLUSION AND SUGGESTION}

\section{Conclusion}

The results showed that (1) Before the stimulation of toilet learning was given to the toddler, showed that $86,7 \%$ had less category in doing toilet learning (2) After the stimulation of toilet learning was given to the toddler, showed that $80 \%$ had good category in doing toilet learning (3) The toilet learning stimulation gives a better and positive effect on the children.

\section{Sugegestion}

It was expected that the place of the study increase the education about the stimulation of the development and the provision of health care information to the community, especially for mothers who had children aged 1-3 years by providing counseling and leaflet about the correct growth stimulation based on the age of children, especially toilet learning.

\section{REFERENCES}

Cahyaningsih. D.S. 2011. Pertumbuhan Perkembangan Anak dan Remaja. Jakarta: CV. Trans Info Media.

Depkes RI.2006. Pedoman Pelaksanaan Stimulasi Deteksi dan Interveni Dini Tumbuh Kembang Anak di Tingkat Pelayanan Kesehatan Dasar.

Notoadmodjo, S. 2006. Ilmu Kesehatan Masyarakat. Jakarta: RinekaCipta.

Nursalam. 2013. Asuhan Keperawatan Bayi dan Anak (Untuk Perawat \& Bidan). Jakarta: Salemba Medika.

Nursalam. 2008. Konsep Dan Penerapan Metodologi Penelitian Ilmu Keperawatan. Jakarta: Salemba Medika.

Warner, P. 2007. Mengajari Anak Toilet Learning. Jakarta: PT Transmedia. 